\title{
Seismic Performance Assessment of Reinforced Concrete Box Culverts under Near and Far Fault Seismic Ground Motion Records
}

\author{
Lawali Moussa Laminou ${ }^{1}$, Wadslin Frenelus ${ }^{2}$, Md Ratan Bhuiyan ${ }^{2}$, Md Ibrahim Bhuyan ${ }^{1}$ \\ ${ }^{1}$ Department of Civil Engineering, College of Civil Engineering and Architecture, China Three Gorges University, Yichang, China \\ ${ }^{2}$ Department of Hydraulic Engineering, College of Hydraulic and Environmental Engineering, China Three Gorges University, \\ Yichang, China \\ Email: ^ellamine83@yahoo.com,wadslin@ctgu.edu.cn,mdratanbhuiyan7@gmail.com,ibrahimbhuyantas@gmail.com
}

How to cite this paper: Laminou, L.M. Frenelus, W., Bhuiyan, M.R. and Bhuyan, M.I. (2022) Seismic Performance Assessment of Reinforced Concrete Box Culverts under Near and Far Fault Seismic Ground Motion Records. World Journal of Engineering and Technology, 10, 40-58. https://doi.org/10.4236/wjet.2022.101003

Received: December 4, 2021 Accepted: February 22, 2022

Published: February 25, 2022

Copyright $\odot 2022$ by author(s) and Scientific Research Publishing Inc. This work is licensed under the Creative Commons Attribution International License (CC BY 4.0).

http://creativecommons.org/licenses/by/4.0/

\begin{abstract}
Studying the critical response characteristics of reinforced concrete box culverts with diverse geometrical configurations under seismic excitations is a necessary step to develop a reasonable design method. In this work, numerical analysis and assessment of reinforced concrete box culverts for seismic loading in addition to standard static loading from dead and live loads is conducted, aiming to highlight the critical difference in the seismic performances between two and three cell box culverts under near and far-fault ground motion. The results show how and where the seismic loading alters the responses of seismic loading of the models including the effect on safety and failure. The geometrical configurations of the culvert combined with the loading scenarios also significantly influence the magnitude and distribution of the seismic responses. The findings of this work shed light on the critical role of the geometrical configurations and shaking event in the seismic responses of reinforced concrete box culverts and this procedure can be applied as seismic assessment method to any culvert shape, size, and material.
\end{abstract}

\section{Keywords}

Box Culvert, Seismic Loading, Near-Fault Ground Motion, Far-Fault Ground Motion, Seismic Assessment

\section{Introduction}

Given the relatively limited land resources in most metropolitan cities, much emphasis has been placed on the construction of more underground structures in order to ensure sustainable development. The resistance of these underground 
structures to natural hazards (such as earthquakes) deserves to be thoroughly investigated.

Road Box Culverts (RBCs) are typically designed on the basis of the Road Earthwork and Culvert Construction Guiding Principle hereinafter referred to as the guiding principle [1] [2]. The guiding principle refers to a culvert with a traditional structure as a conventional culvert and determines its application range [3]. Furthermore, this guiding principle states that conventional culverts satisfying these structural conditions are considered to exhibit a seismic performance, even without a seismic design; it is possible to determine these structural conditions solely with a static design. This is because when an earthquake occurs, RBCs are thought to behave in unison with the surrounding ground, and therefore, the lining is not subjected to large seismic forces [4]. Another reason is that past major earthquakes did not damage RBCs [5]. Even after earthquakes that have caused serious damage to geotechnical structures no significant damage to RBCs was reported [6].

In recent years, structures with enlarged sectional dimensions have become common. As a result, culverts are typically designed to withstand static loading without regard for seismic events. Prudence dictates, however, that large culvert projects installed in seismically active areas be designed to withstand structural damage caused by seismic events. As these structures do not meet the aforementioned structural conditions of conventional culverts, they require not only a static design but also a seismic design, creating the need for a method that can be applied to RBCs [7]. However, there is no standard seismic design methodology because of the absence of data regarding major damage caused by past earthquakes. Several seismic design methods have been applied to rectangular underground structures, e.g., cut-and-cover tunnels, which are structurally similar to RBCs, and various researchers have developed ways to evaluate their seismic behavior and seismic design [8] [9] [10] [11] [12]. It is presumed that the results of those studies are also applicable to the seismic design of RBCs because the cross-section of RBCs and the material of members of RBCs are similar to the underground structures described above. However, RBCs have unique structural features, e.g., no haunch at the bottom of the sidewalls and a wide cross-section. Although there have been previous experimental studies [13] [14] and validation of dynamic analyses has been conducted in this area, these studies investigated RBCs under different seismic loading condition is still needed. Therefore, in the present study, seismic assessment of two models of RBC is conducted with near and far fault earthquakes loading to verify the seismic behavior of RBCs and establish a way to evaluate their seismic behavior. A numerical analysis using an elastoplastic finite analysis method is carried out and results were discussed.

\section{Development of Finite Element Model}

\subsection{Description of the Model}

Analytical modeling of the reinforced concrete box culverts is achieved by using 
the Abaqus software package program. The objective of the analysis is to evaluate the seismic behavior of reinforced concrete RBC under near and far fault earthquakes. Two examples of RBCs are investigated under the effects of the near fault records. The structures consist of two and three cells RBC. The RBCs are built to provide free flow of a stream under a highway line. The cross section dimensions in meter $(\mathrm{m})$ are reported in Figure 1. Lateral abutments are obviously subject to the earth pressure (Figure 2), linearly varying from qtop to qbottom. The top slab covered by a road pavement and a surcharge over road, yielding the uniformly distributed loads referred to as Qroad pavement and Qsurcharge over road, respectively (Figure 2). The values of the loads represented in Figure 2 are collected in Table 1. Figure 3 shows the finite element models of the box culverts.

Embedded Element is a technique used to place embedded nodesat desired locations with the constraints on translational degrees-of-freedom on the embedded element by the host element [15] [16]. Both the rebar cages were modeled as the embedded region in concrete using constraints in the interaction module, and making the concrete the host. Thus, rebar elements can only have translations/rotations equal to those of the host elements surrounding them [17] [18].

The RBC sections were considered in the mesh generation, and it was regarded as a three-dimensional solid element for the box culverts, and three dimensional
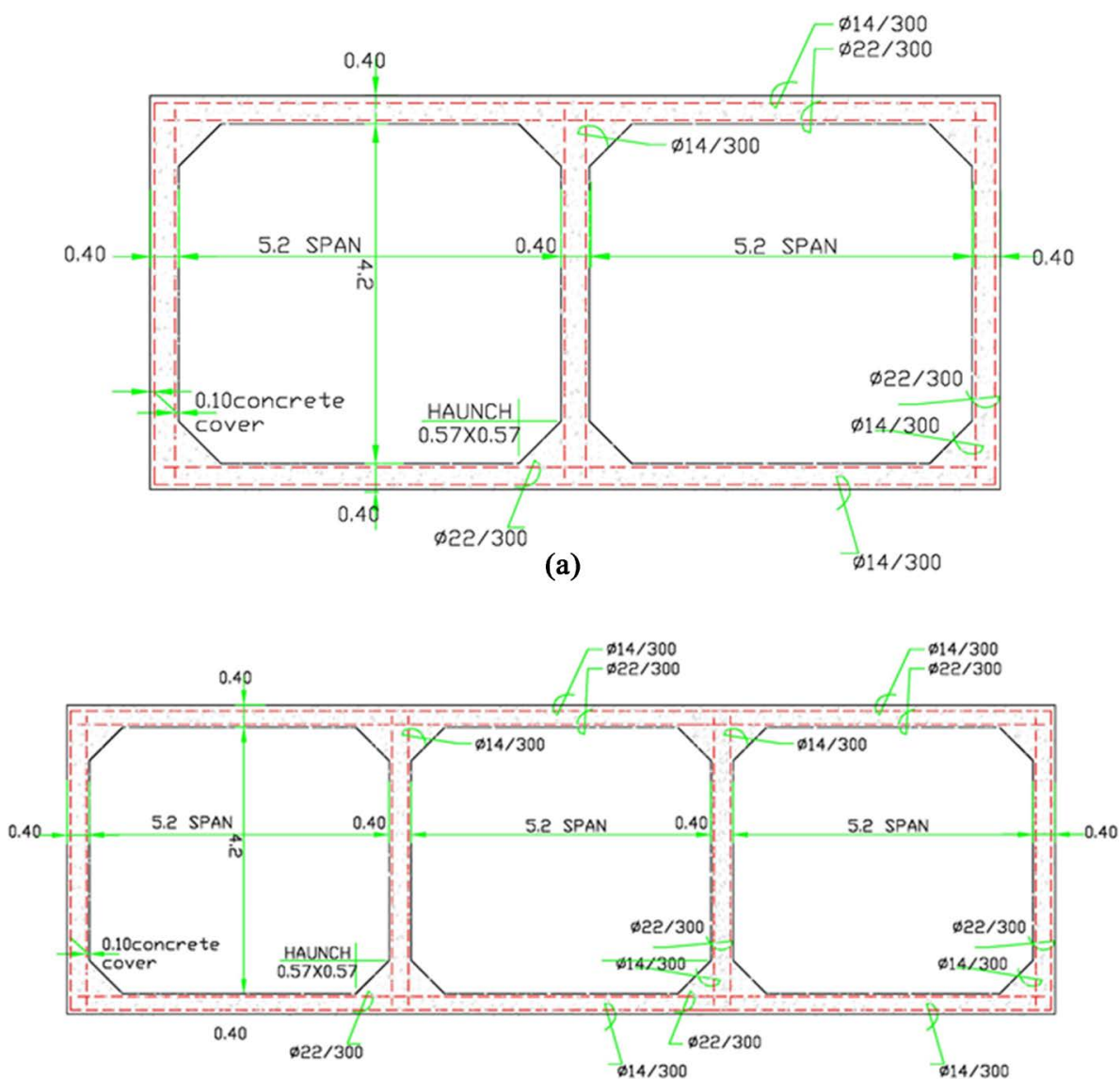

(b)

Figure 1. Sections View (a) Double Cell Box Culvert; (b) 3 Cell Box Culvert. 


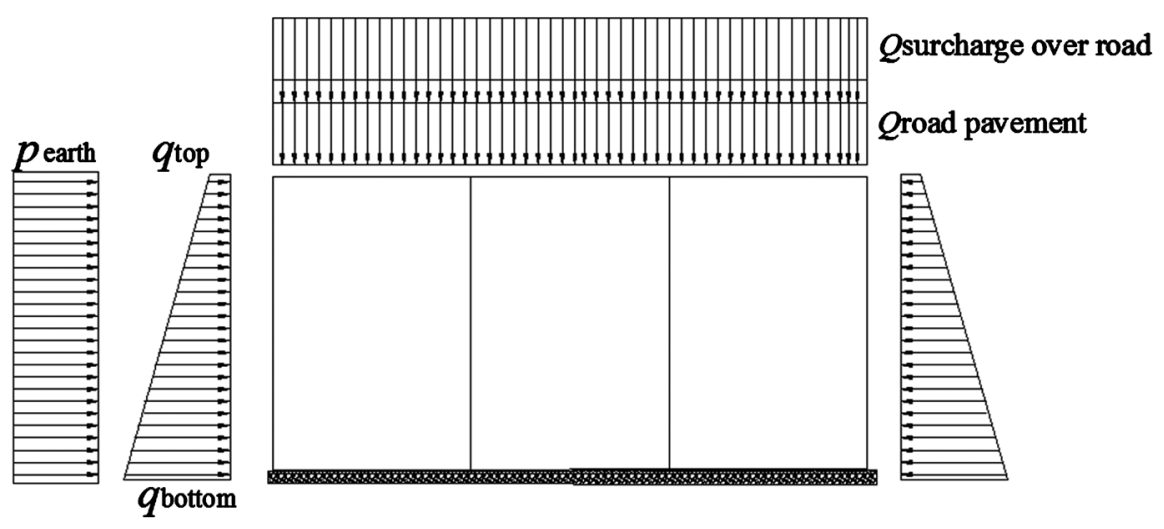

Figure 2. Applied loads.

Table 1. Values of the applied loads.

\begin{tabular}{cc}
\hline Parameter & Value $[\mathrm{KN} / \mathrm{m}]$ \\
\hline Qroad pavement & 47.5 \\
Qsurcharge over road & 28.5 \\
qtop & 30.95 \\
qbottom & 93.65 \\
pearth & 20 \\
\hline
\end{tabular}

(a)
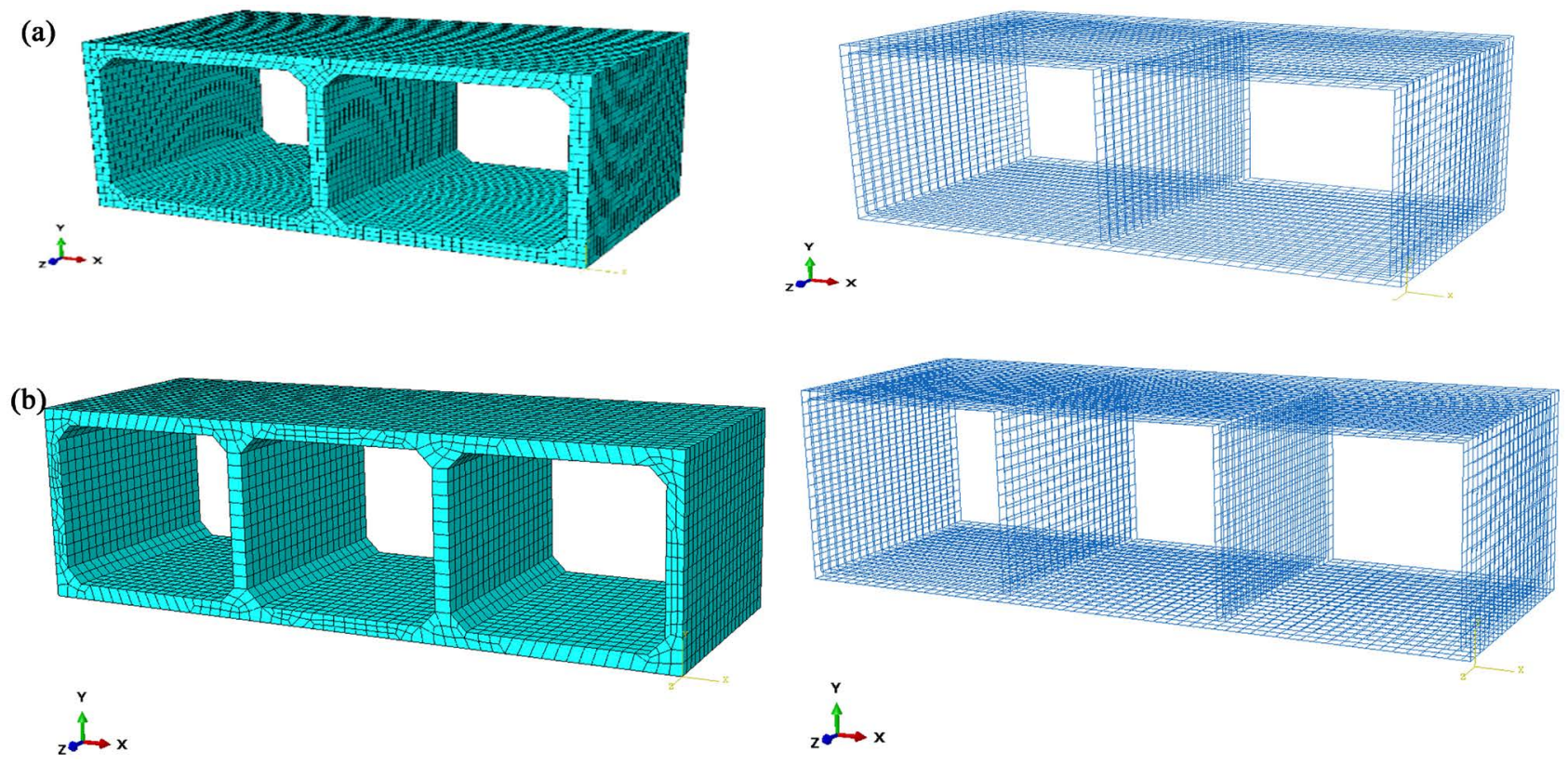

Figure 3. The finite element models of the box culverts.

wire elements rebars. The RBC section elements and rebars elements have meshed separately. The mesh element was generated on the RBC sections as shown in Figure 3.

\subsection{Mechanical Parameters}

Concrete grade C30 and reinforced with steel bars with nominal yield strength fy 
$=500 \mathrm{MPa}$ are considered. Beam-column connections are modeled as infinitely rigid links. The following analyses are carried out taking account of material nonlinearity. A rigid-perfectly plastic moment-rotation relationship is adopted as plastic hinge constitutive law. The nonlinear concrete and rebar model parameters are given in Table 2 and Table 3. The density, Poisson' ratio and elastic modulus of the materials are presented. The concrete damage plasticity model is employed to describe the inelastic behavior of concrete elements in the plastic stages, and the input parameters are presented. The tensile cracking and the compressive crushing

Table 2. Parameters of plasticity damage model of concrete.

\begin{tabular}{|c|c|c|c|c|c|c|c|}
\hline \multicolumn{2}{|c|}{ Dilation angle } & \multicolumn{2}{|l|}{ Eccentricity } & $\mathrm{fbo} / \mathrm{fco}$ & $\mathrm{K}$ & \multicolumn{2}{|c|}{ Viscosity parameter } \\
\hline \multicolumn{2}{|l|}{35} & 0.1 & \multicolumn{2}{|c|}{1.16} & .6667 & \multicolumn{2}{|c|}{0.007985} \\
\hline \multicolumn{2}{|c|}{ Density $\left(\mathrm{kg} / \mathrm{m}^{3}\right)$} & \multicolumn{2}{|c|}{ Poisson' ratio (v) } & \multicolumn{4}{|c|}{ Elastic modulus (Es), $\mathrm{MPa}$} \\
\hline \multicolumn{2}{|c|}{2400} & \multicolumn{2}{|r|}{0.20} & \multicolumn{4}{|c|}{30100} \\
\hline \multicolumn{2}{|c|}{ Compressive Behavior } & \multicolumn{2}{|c|}{ Compressive Damage } & \multicolumn{2}{|c|}{ Tensile Behavior } & \multicolumn{2}{|c|}{ Tensile Damage } \\
\hline $\begin{array}{l}\text { Yield Stress } \\
(\mathrm{MPa})\end{array}$ & $\begin{array}{c}\text { Inelastic } \\
\text { Strain }\end{array}$ & $\begin{array}{c}\text { Damage } \\
\text { Parameters }\end{array}$ & $\begin{array}{l}\text { Inelastic } \\
\text { Strain }\end{array}$ & $\begin{array}{c}\text { Yield } \\
\text { Stress (MPa) }\end{array}$ & $\begin{array}{c}\text { Cracking } \\
\text { Strain }\end{array}$ & $\begin{array}{c}\text { Damage } \\
\text { Parameters }\end{array}$ & $\begin{array}{c}\text { Cracking } \\
\text { Strain }\end{array}$ \\
\hline $8,060,000$ & 0 & 0 & 0 & 878,000 & 0 & 0 & 0 \\
\hline $17,600,000$ & 0.000137 & 0.0562 & 0.000104 & 2320,000 & 0.000103 & 0.445215 & 0.000321 \\
\hline $20,900,000$ & 0.0005 & 0.123 & 0.000325 & 882,000 & 0.000387 & 0.606951 & 0.00058 \\
\hline $21,200,000$ & 0.000721 & 0.415 & 0.002 & 185,000 & 0.00168 & 0.692214 & 0.000821 \\
\hline $20,100,000$ & 0.00191 & 0.709 & 0.00463 & 68,700 & 0.0044 & 0.74539 & 0.001055 \\
\hline $17,900,000$ & 0.00348 & 0.855 & 0.00943 & & & 0.781942 & 0.001286 \\
\hline $16,900,000$ & 0.0043 & 0.938 & 0.0225 & & & 0.808721 & 0.001514 \\
\hline $15,800,000$ & 0.00522 & 0.961 & 0.0348 & & & 0.829245 & 0.001741 \\
\hline $14,800,000$ & 0.00623 & & & & & 0.845512 & 0.001967 \\
\hline $11,600,000$ & 0.0102 & & & & & 0.858746 & 0.002192 \\
\hline $5,210,000$ & 0.0319 & & & & & & \\
\hline $4,160,000$ & 0.0419 & & & & & & \\
\hline $3,100,000$ & 0.0586 & & & & & & \\
\hline
\end{tabular}

Table 3. Reinforcement steel material Plastic Parameters.

\begin{tabular}{ccc}
\hline Fracture Strain & Stress Triaxiality & Strain Rate \\
\hline 0.1 & 1 & 1 \\
\hline Density $\left(\mathrm{kg} / \mathrm{m}^{3}\right)$ & Poisson' ratio (v) & Elastic modulus (Es), $\mathrm{MPa}$ \\
\hline 7800 & 0.30 & 210000 \\
\hline Yield Stress $[\mathrm{MPa}]$ & Plastic Strain & \\
\hline $33,5000,000$ & 0 & \\
$437,000,000$ & 0.1377 & \\
\hline
\end{tabular}


are the two main failure mechanism for the concrete damaged plasticity model.

\subsection{Input Earthquake Motion}

In general, earthquakes have different properties such as peak acceleration, duration of strong motion and different ranges of dominant frequencies and therefore have different influences on the structure. The El Centro and Kobe records played also invaluable role in nonlinear, inelastic structural response computations when there were no other, credible strong motion records available. For the purposes of the present analysis, to the response of an RBC during a strong earthquake, two earthquake excitations are used in this study, two strongest records were selected: 1) El Centro $(\mathrm{Mw}=6.95)$ with duration of strong motion in the range of 1.5 - $5.5 \mathrm{~s}$ and dominant frequencies in the range $0.39-6.39 \mathrm{~Hz}$, its intensity can be described by Peak Ground Acceleration of PGA $=0.28$ g. 2) Takatori record from the 17 January 1995, Kobe earthquake $(\mathrm{Mw}=6.9)$ with duration of strong motion in the range of $7.5-12.5 \mathrm{~s}$ and dominant frequencies in the range $0.29-1.12 \mathrm{~Hz}$ and is characterized by PGA = $0.61 \mathrm{~g}$.

Kobe earthquake record can be treated as a typical, near fault, as its epicentral distance is near fault records with a distance to source of less than $5 \mathrm{~km}$ and El Centro earthquake with epicentral distance of $27 \mathrm{~km}$ was selected to illustrate far-fault ground motion characteristics. Ground motion parameters include the peak ground acceleration (PGA), peak ground velocity (PGV), peak ground displacement (PGD), frequency content, and response spectra. The shape of acceleration, velocity, and displacement time histories and their corresponding frequency content and response spectrum is shown in Figure 4.

\section{Numerical Simulation Results}

Strong earthquakes could make geometric nonlinearity of the structure enhanced, which leads to large deformation under the excitation of rare seismic intensity. The seismic analysis has been fulfilled using finite element software Abaqus. The earthquake wave propagates along $\mathrm{x}$ direction. The main results obtained from the numerical analyses carried out will be summarized. The acceleration and displacement response of the box culverts, as well as the bending moments, shear forces, axial forces and stress-strain responses of the box culverts were studied. In particular, the responses of the two box culvert structures will be compared and used to describe and discuss the global and local behavior of their seismic resisting systems, when subjected to near and far fault earthquake excitations. A general overview of their prevailing characteristics is given here, and specific aspects are referenced when needed to explain key points. Particular care is paid to the response of the side wall and slab element, showing their influence on the global structural performance of these two box culvert prototypes. Figure 5 shows the visualization of the Jobs at the end of the shaking events step. 

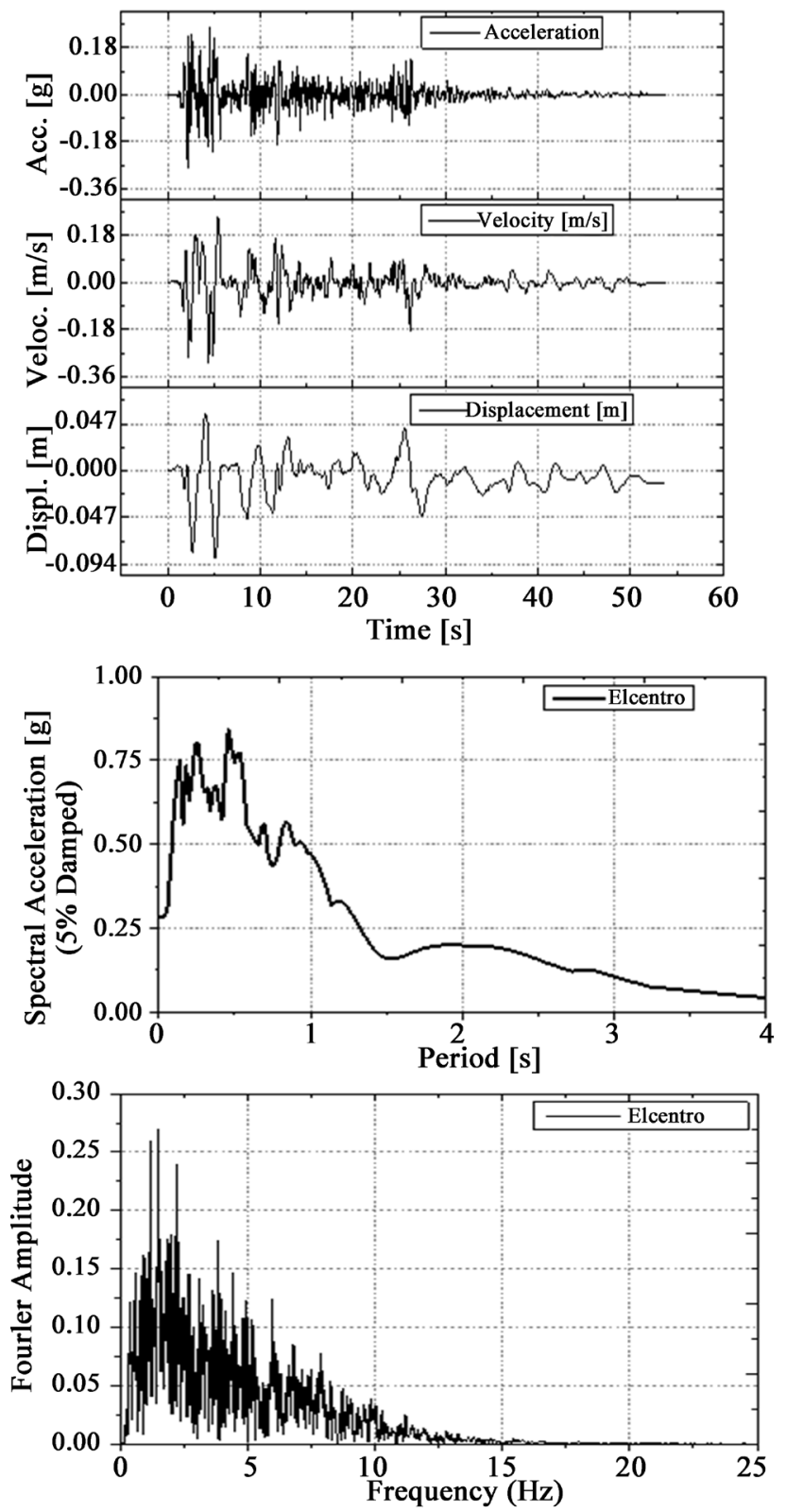

(a)
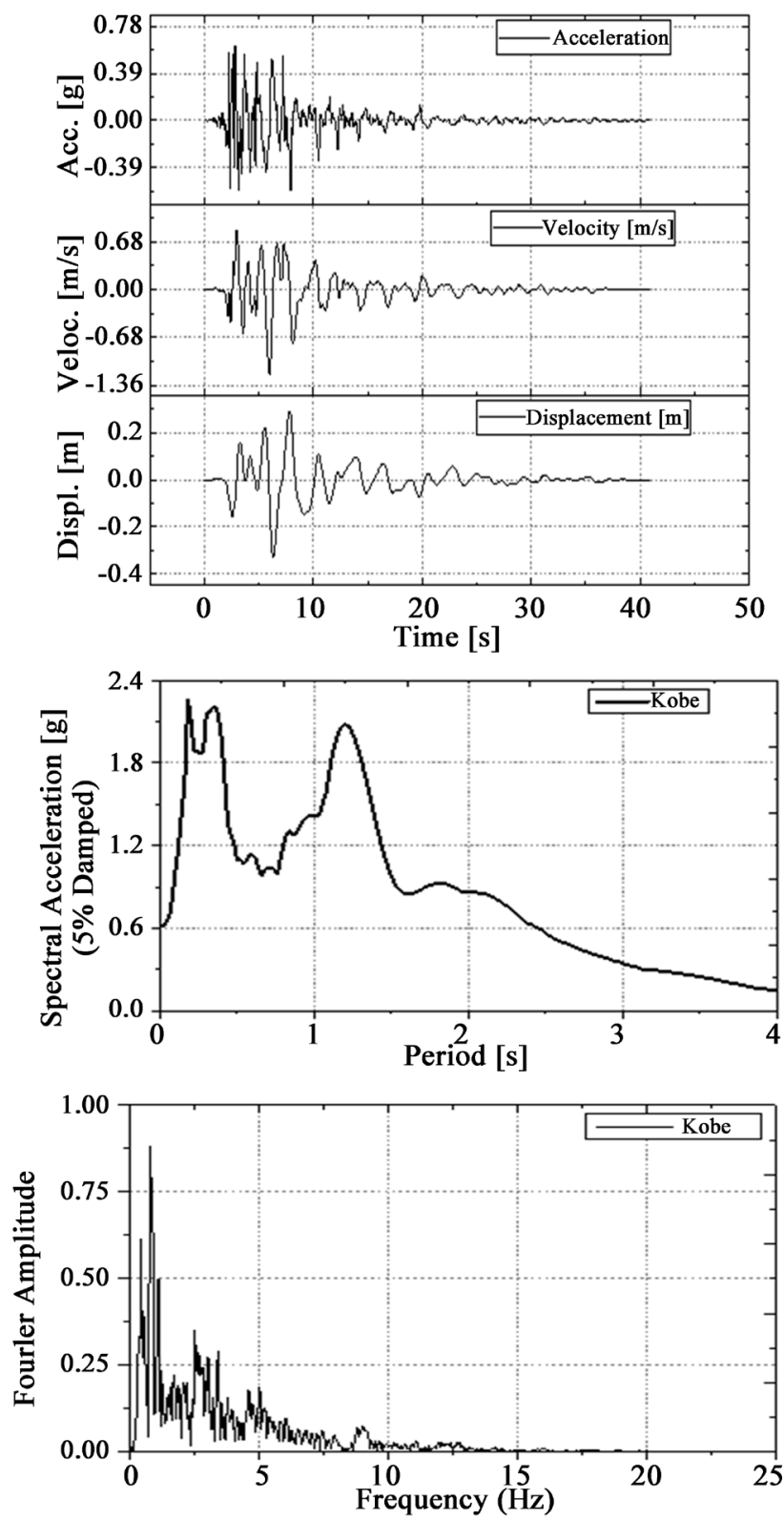

(b)

Figure 4. Input motions informations: (a) El Centro and (b) Kobe earthquakes.

\subsection{Displacement Responses}

RBCs are short-span structures, and their mechanical properties are affected by side walls. On the one hand, side walls constrain vertical deformation of top slab, and on the other hand, they bear the lateral pressure of the soil to RBC. The displacement results of the side walls of various RBC structures are graphically drawn in Figure 6 in order to compare and analyze the simulated values. In Figure 6, a positive value of the $\mathrm{X}$-axis indicates that the side wall is deformed outward, and a negative value indicates that the side wall is deformed inward. Side wall in rotated and horizontal direction is deformed due to vertical downward displacement of top slab under load. The horizontal displacement of four 


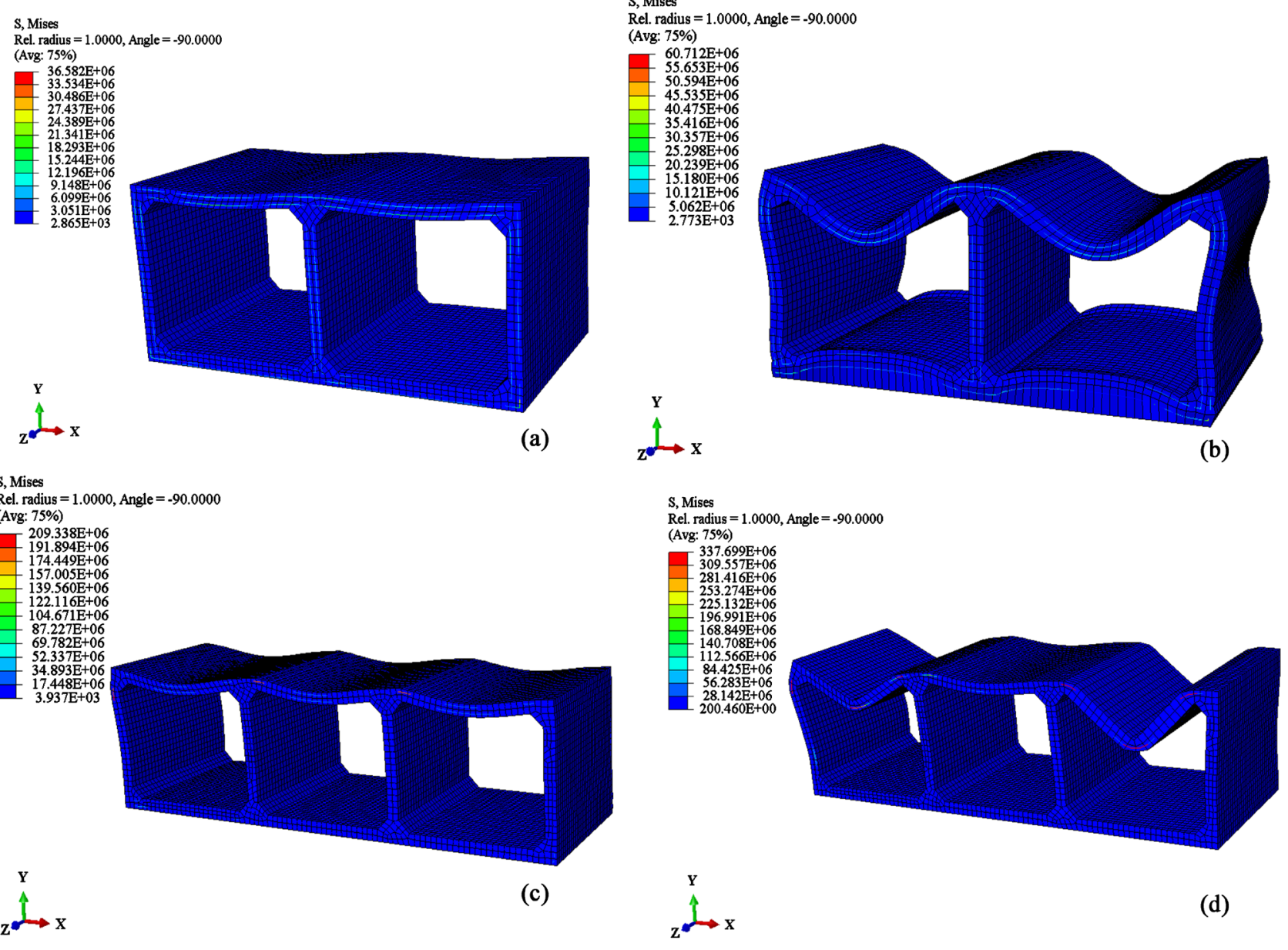

Figure 5. Typical contours for Von Mises stress: El Centro: (a) and (c); Kobe: (b) and (d).
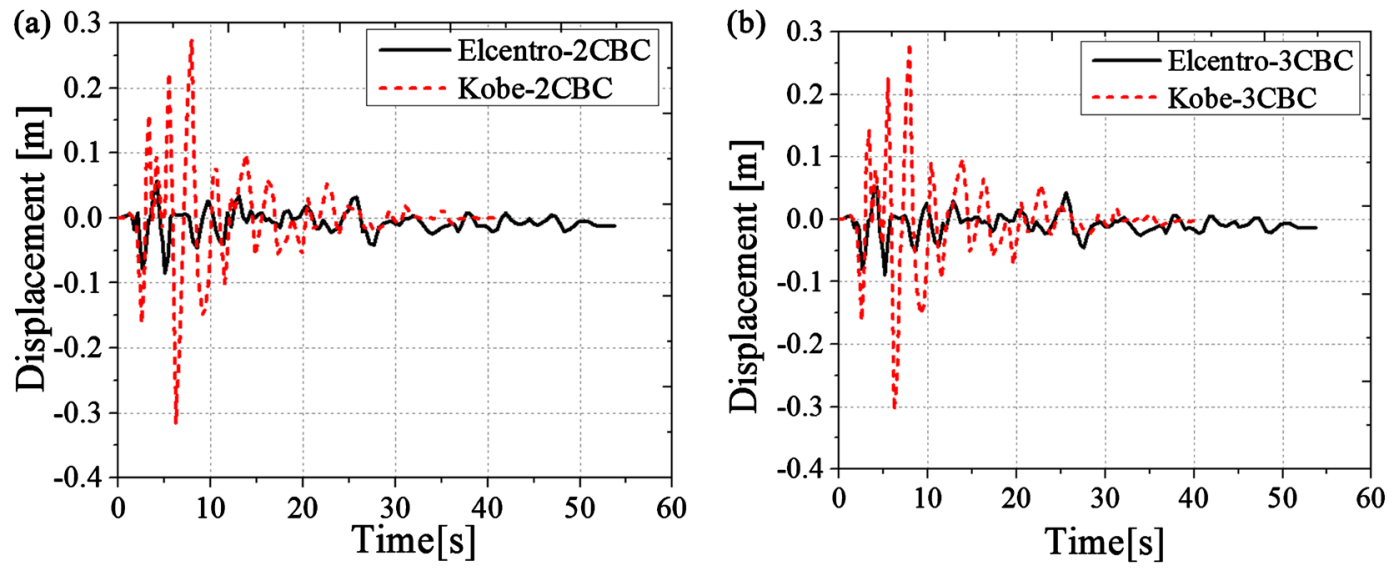

Figure 6. Displacement responses: (a) Double Cell Box Culvert (b) 3 Cell Box Culvert.

types of RBC side walls presents a nonlinear distribution along the wall. The change of horizontal displacement of the side walls of RBCs from bottom to top shows a regular pattern that increases first and then decreases. As can be seen from Figure 6, the results of the inelastic response-history analysis give the distributions of displacement. The history analysis values of the displacement under 
two earthquake waves for the two models are illustrated in Figure 6. As a whole, it can be seen that; the largest lateral displacement is located under the excitation of near fault seismic intensity. Moreover, the two cell RBC shows the highest displacement result with a value of $0.317 \mathrm{~m}$, while the three cell $\mathrm{RBC}$ has a value of $0.306 \mathrm{~m}$. Therefore, it can be observed that there is a slight difference between the displacement results of the two models under the same wave excitation. Considering that this situation is related the load increases, the value of the maximum horizontal displacement increases upward along the side wall. Therefore, when designing a RBC under a high embankment, it is recommended to choose different seismic ground motion for time-history analysis of the structure which can provide the seismic responses of RBCs large enough to induce the plastic deformation. Moreover, in the case of health monitoring of the RBC structure, the maximum horizontal displacement shall occur within the range of 0.6 to 0.7 of the height of side wall for the integral structure.

\subsection{Acceleration Responses}

Figure 7 shows the distribution of acceleration values in the positive direction at each shaking level (far and near fault excitation). Top and bottom level time history acceleration responses are presented, respectively. Although the distribution
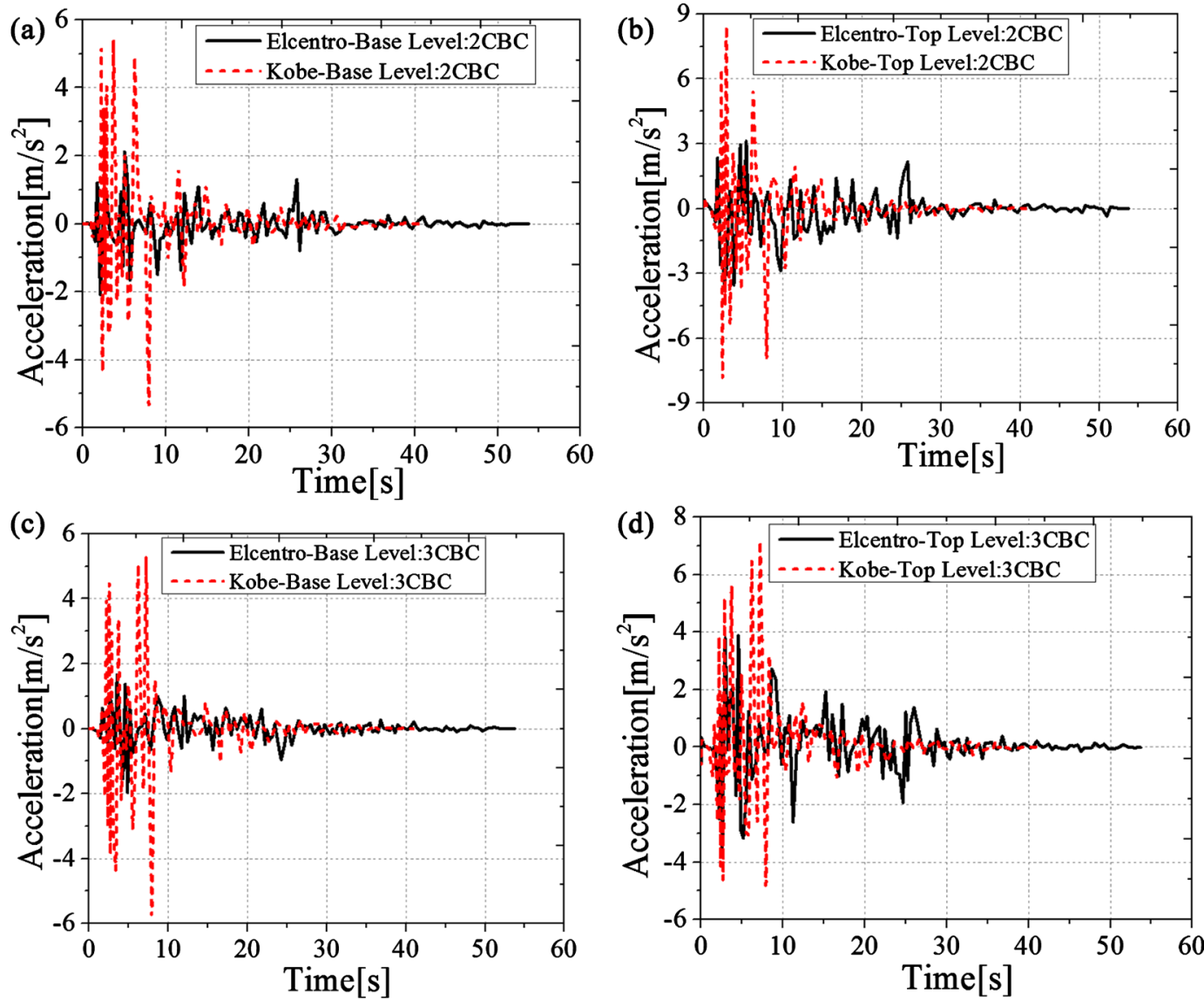

Figure 7. Acceleration responses: Base Level: (a) and (c); Top Level: (b) and (d). 
is shaped differently in each case, in all cases, the distributions of the ground and RBC response acceleration values show discrepancy from a far fault shaking event. The fact that the ground and RBC acceleration values do not coincide indicates that they might be independent of each other.

It can be seen that for all two models and for both ground motions the analysis produces very good estimates. As shown in the figure, here also the results from Kobe seismic load have large responses and two cell BC shows highest response. Some studies have suggested that the variation of acceleration demands along the height of structure and in particular the ratio of the peak floor acceleration demand to peak ground acceleration is independent of the period of vibration of the structure. However, as shown Figure 7, the acceleration profile can change significantly from one model to another. Figure 7 clearly shows that the responses can be rather different when different models and shaking event effect are considered. It can be seen that the acceleration responses can either be increased or decreased with different shaking event, and there is no evidence that the shaking event effect will definitely enlarge the acceleration responses of these models. However, there is a trend from these results that the influence of near fault shaking effect increases as the cell decreases. In order to further investigate the influence of shaking event effect on these box culvert structures, the acceleration responses of the two culverts at bottom and top are compared. One can see that from these comparisons, the accelerations responses along $\mathrm{x}$-direction under far fault excitation on bottom and top of the culverts are mostly dropped compared to bottom and top results under near filed excitations. Special attention should be paid that the peak accelerations on top of the culverts are mostly enlarged by near fault shaking effect with a percentage increase can reach to $158 \%$ for two cell box culvert and $275 \%$ for three cell box culvert.

\subsection{Seismic Bending Moment}

Bending moments are required for design purposes. Figure 8 compares the calculated bending moments obtained from the numerical models for the culvert top slab and side wall in during all of the seismic events. Some design codes as the Canadian Highway Bridge Design Code (CHBDC; CSA 2006a), appreciate that the dynamic analysis indicates that there are significant bending moments induced by the horizontal component of the earthquake. As can be seen, the bending moment values may change depending of the excitation scenarios. The bending moment values at the top slab and side wall are not close. As the earthquake shaking increases, the difference is expected to increase. The bending moment results obtained from the far fault as from the near fault event on the top slab displays negative values at the edges and positive values at the centre. On the side wall, the bending moment from far fault events at the side wall of the two cell box culvert varies almost linearly from a high negative values and decreases at the other edge. On the other hand, for the three cell box culvert, the side wall bending moment displays negative values at one edge and positive value at the 



Figure 8. Moment responses. Side Wall: (a) and (c); Slab Element: (b) and (d).

other, with curvy distribution in between.

All bending moment responses of top slab and side wall from the near fault shaking represent the maximum responses of the axis compared to the obtained bending moment responses from the bending moment responses due to far fault excitation. Thus, comparing the total bending moment responses from different models, the moment at the center of top slab reduces tremendously in a triple cell box culvert as compared to that in a double cell culvert. The reduction in central moment is of the order of 36\% under far fault event and 34\% under near fault excitation. However, the side wall moments reduce by $55 \%$ under far fault event and $41 \%$ under near fault shaking event. It can be observed that, the increase in cell of culvert leads to substantial decrease in bending moment at the center of all the members and particularly at the side walls. Considering all the models and compared the top slab with the side wall bending moment results, it can be clearly seen that the responses from the top slab are on higher side than the side wall moments. On the other hand, in a double and triple cell box culvert the top and bottom slabs are continuous therefore; the support moments are on higher side than the central moment. These observations suggest that the seismic bending moments are significant and the total bending moments should be considered in the design as a loading combination case. This is particularly impor- 
tant for culverts situated in areas with high seismicity, as the seismic bending moment will increase as the PGA increases.

\subsection{Axial Force Responses}

Regarding the axial-force distribution, Figure 9 shows the total axial forces developed in the top slab and side wall elements under the two different seismic scenarios. The distribution of axial force in the elements isn't symmetrical. The effects of the application of near fault seismic load increase considerably the axial loads in the top slab members to, but don't show highly impact on the side wall. The maximum axial-force distribution occurs in the three cell box culvert top slab under near fault shaking event and is 12 percent increase over the maximum under far fault shaking event, moreover the locations of maximum response under the two events are nearly same. It should be stated here that the variation of the force gives rise to reduction in the model shear strength due to reduction or even loss of the concrete contribution. Moreover, this variation has a significant effect on the moment-curvature and axial load-bending moment interaction diagram of the R.C. element. Findings from recent researches indicated that the section capacity could be significantly reduced, especially for the exterior and inferior element.
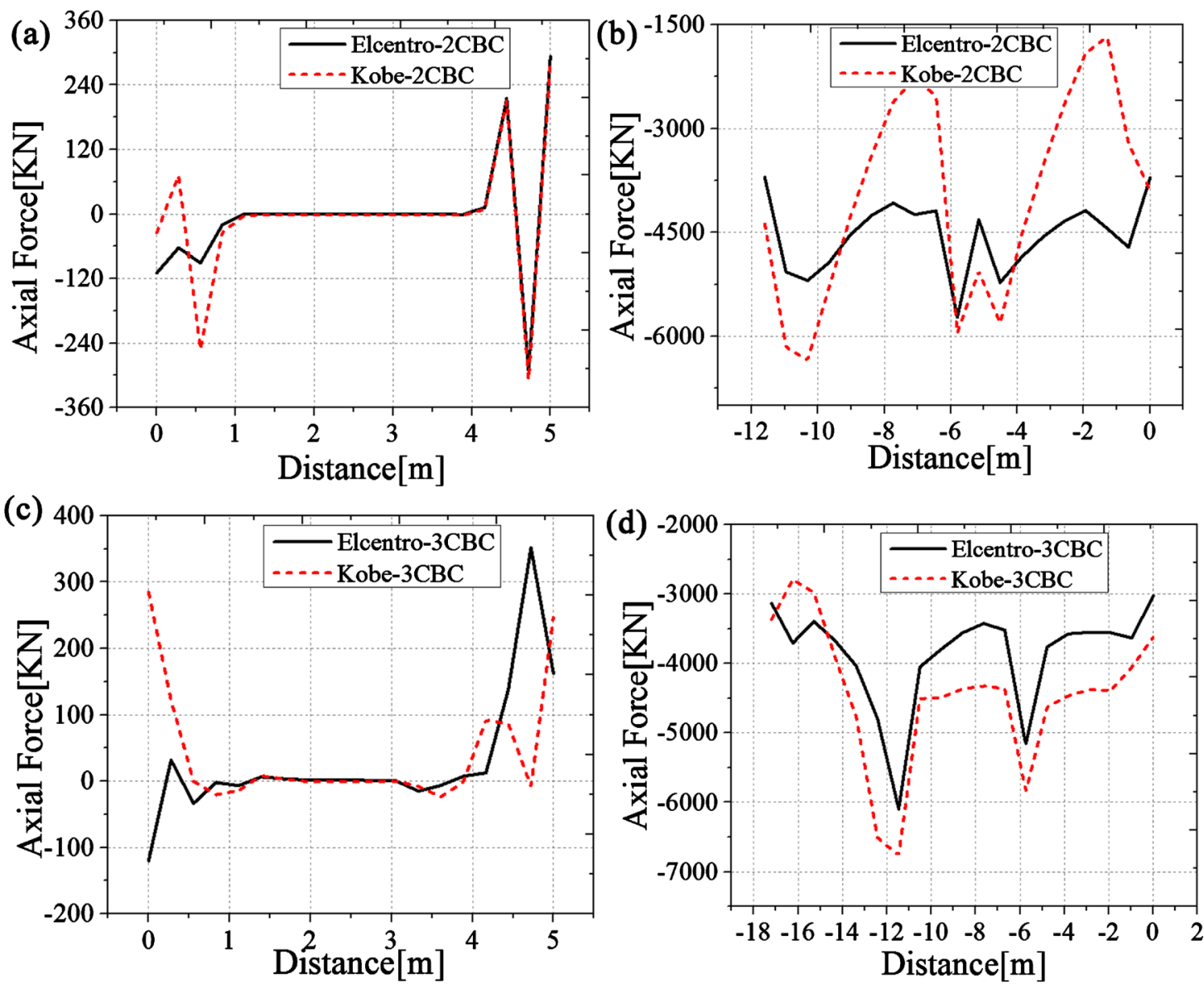

Figure 9. Axial force responses: Side Wall: (a) and (c); Slab Element: (b) and (d). 


\subsection{Shear Force Responses}

Figure 10 shows the comparison made for top slabs and side walls spans shear envelopes. As can be seen in the figures, results under the near and far fault event in the side walls follow nearly same curves. However, deviation exists between near and far fault event results, the graph for the side walls span shows little to no change in shear force. The side walls shear force in the models under near fault intensity earthquakes is close to that in the models under far fault event. In all instances, the change tended to be very small. While results of the top slab from the two cell model show important gap under near fault intensity earthquake compared to the three cell model. General observations can be made to all two culverts results that the elements condition results are higher when near shaking event is considering. The difference between the two conditions becomes more significant at slab elements and the finite element results indicated that an average of $8.44 \%$ increase is observed in the side wall and $35.42 \%$ in the top slab from two cell box model when near fault event is considered. An average increase of $0.27 \%$ in the side wall and $2.95 \%$ in the top slab are obtained from the three cell model when near fault excitation is considered.

\subsection{Stress-Strain Behavior Responses}

In this section, seismic load effects on stress and strain of box culverts were also
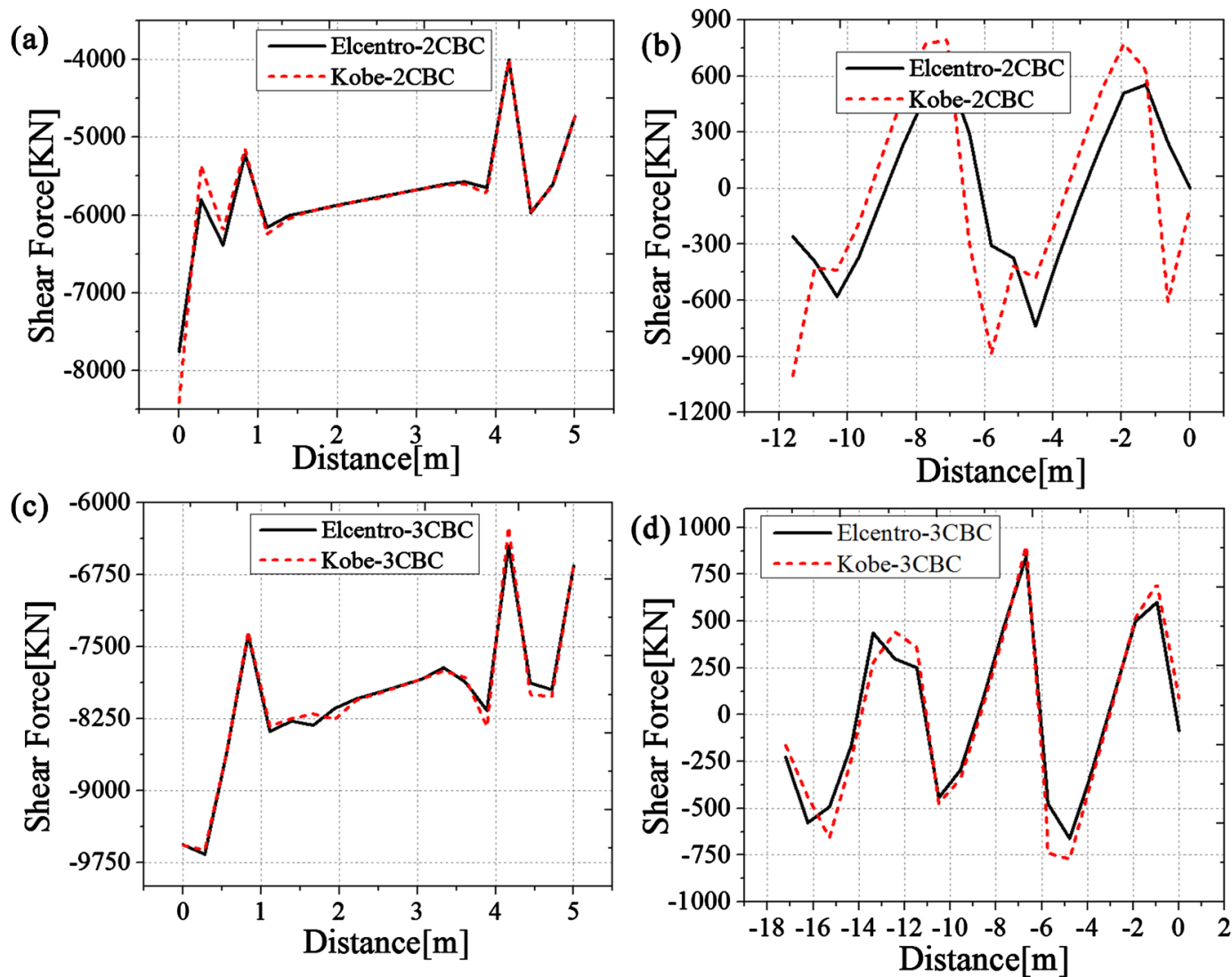

Figure 10. Shear force responses: Side Wall: (a) and (c); Slab Element: (b) and (d). 
estimated with the validated dynamic analysis based on shaking event scenarios. The stress and strain results at top and bottom of the box culverts are extracted. The result is shown in Figure 11. Analysis of the stress distribution in Figure 11 shows the distribution law of the principal stress. Figure 12 and Figure 13 show that the stresses in the horizontal direction (S11) and in the vertical direction (S22) for each configuration. The strain variation law of the section is obtained by sorting and summarizing the strain data of measurement points. A positive strain indicates that the concrete is being pulled, and a negative value indicates that the concrete is under pressure. After the RBC structure cracking, the strain distribution of the section shows the nonlinear distribution law, and the position of the neutral axis increases in the vertical direction with the increase of the load, indicating that the bending and tensile action of the concrete under the section is more obvious. As shown, in Figure 11, the amplitudes of the peaks increased gradually not at the same rate, but in the analysis, the peak amplitude at the positive side exceeded that at the negative side. This phenomenon may have occurred because of the following: in the analysis, the amount of displacement on the positive side was larger than that on the negative side during one period, which generated discrepancy of displacement.

By comparing the two shaking events on the integral RBC structures, the responses of the two models components show significant large differences under the different seismic waves with the same model and standard. It can be found
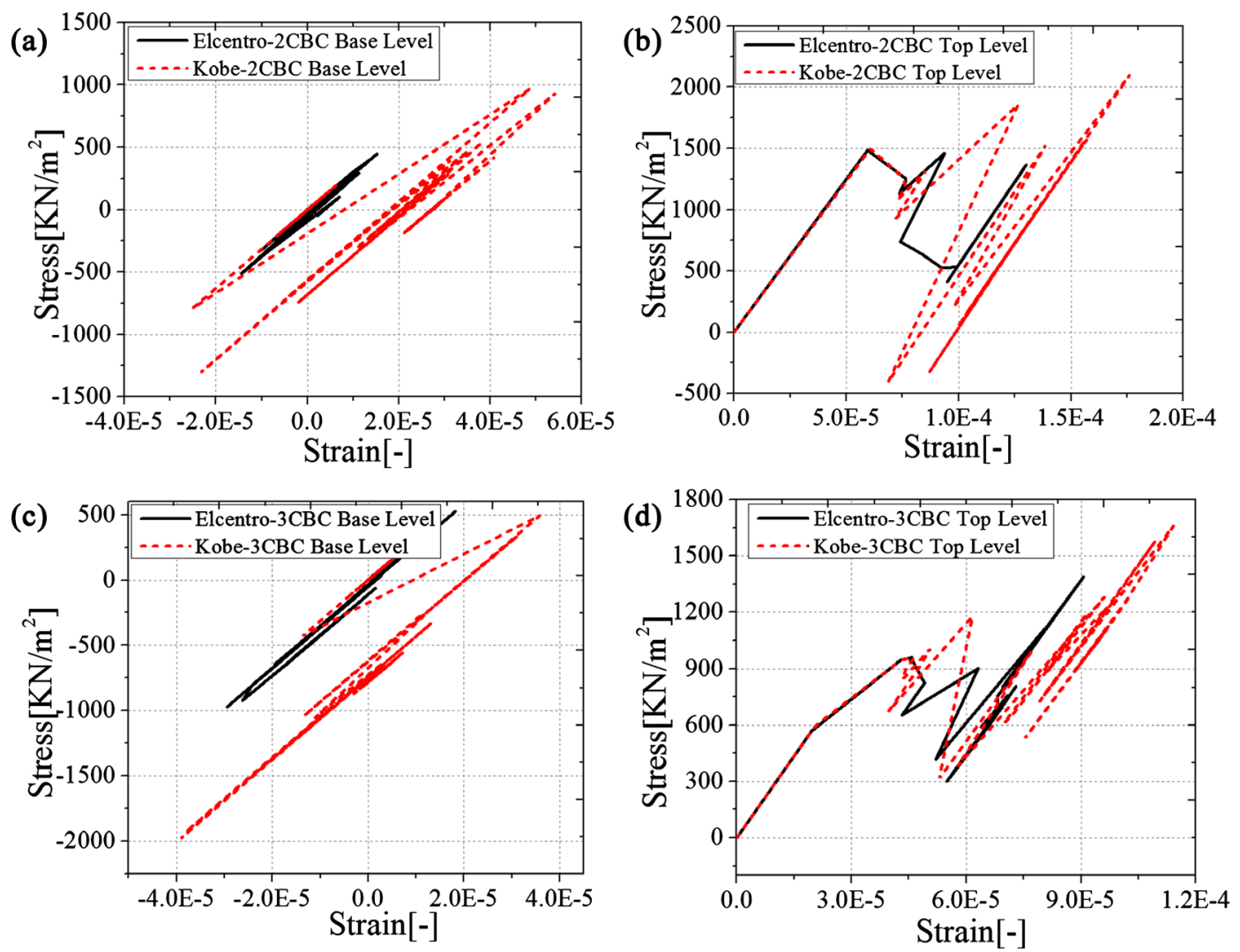

Figure 11. Stress-strain responses: Base Level: (a) and (c); Top Level: (b) and (d). 


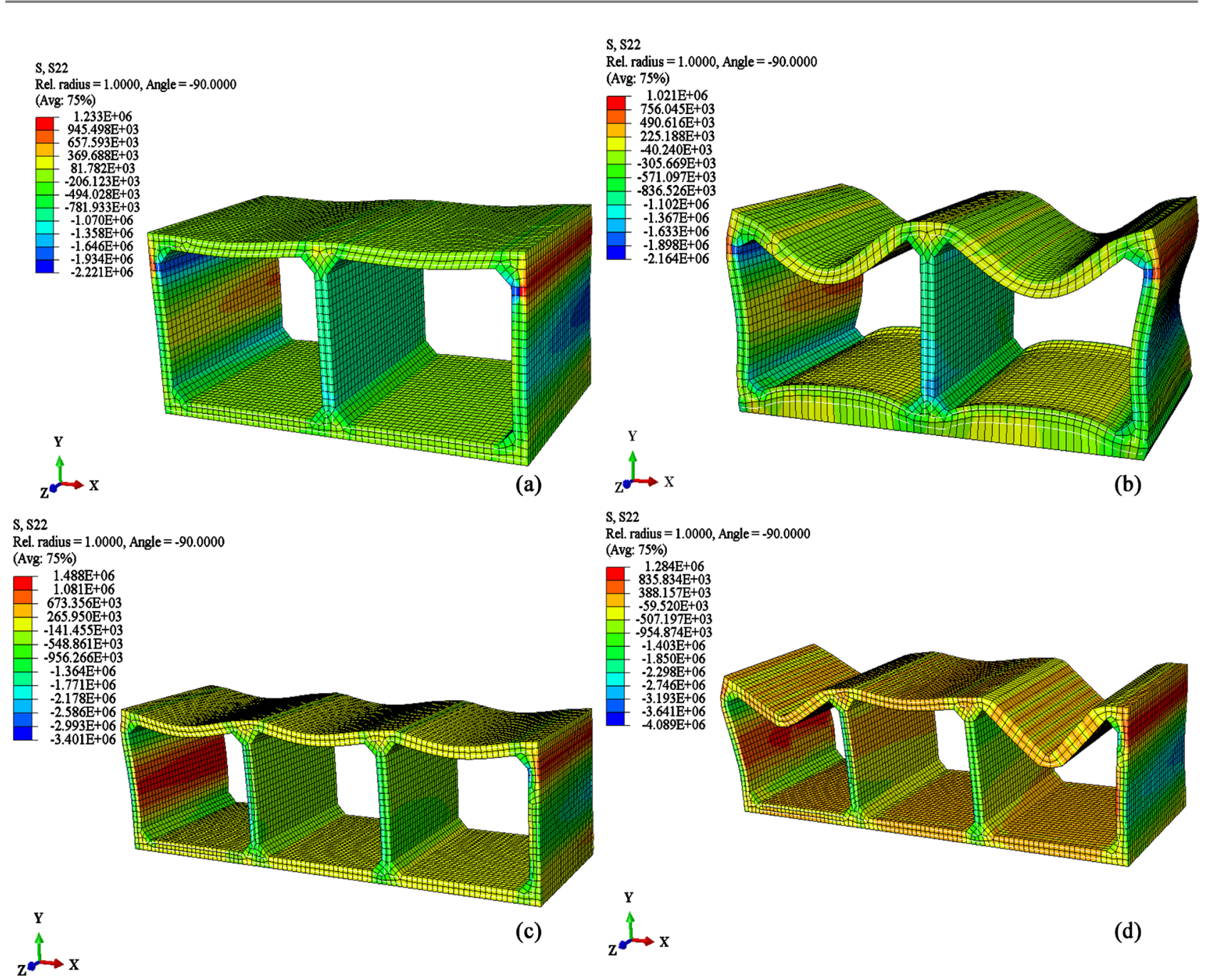

Figure 12. The vertical direction stresses (S22) contour: El Centro: (a) and (c); Kobe: (b) and (d).

that different seismic waves have great effects on the structure responses. The near filed ground motion produces a large horizontal displacement, releasing the highest stress of concrete on the top of the external surface of side walls. Moreover, near fault excitations show large strain responses, where the highest response gets be observed from the two cell RBC. It is therefore considered that the possible highest crack origin can be under the multiaxial strain state in the two cell RBC when subjected to the near fault excitation because of geometric discontinuity. As shown in Figure 11, under different shaking event measures, both the stress and strain on the box culverts increased with position level and the relation between stress and strain change shape. This finding can be attributed to the fact that the thickness of the covering soil influenced the stress and strain on the roof, in that the thicker and denser the soil cover, the higher both the stress and strain values.

\section{Conclusions}

This study developed the finite element analysis of the differential settlement 


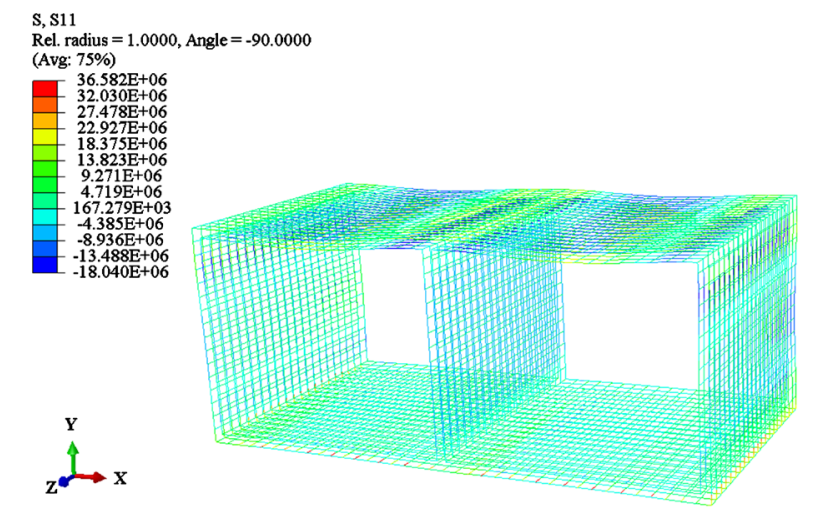

(a)

S, S11

Rel. radius $=1.0000$, Angle $=-90.0000$

(Avg: 75\%)

$\quad 60.712 \mathrm{E}+06$
$54.027 \mathrm{E}+06$
$47.343 \mathrm{E}+06$
$40.658 \mathrm{E}+06$
$33.974 \mathrm{E}+06$
$27.829 \mathrm{E}+06$
$20.604 \mathrm{E}+06$
$=13.920 \mathrm{E}+06$
$7.235 \mathrm{E}+06$
$550.69 \mathrm{E}+03$
$-6.134 \mathrm{E}+06$
$-12.88 \mathrm{E}+06$
$-19.503 \mathrm{E}+06$

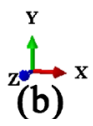

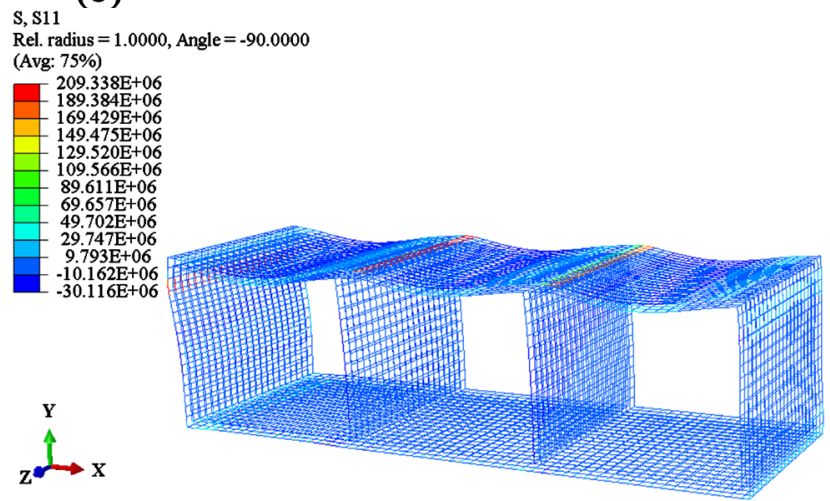

(c)

S, S11

Rel. radius $=1.000$
(Avg: $75 \%$ )

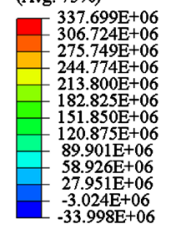

Y

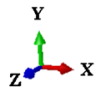

(d)
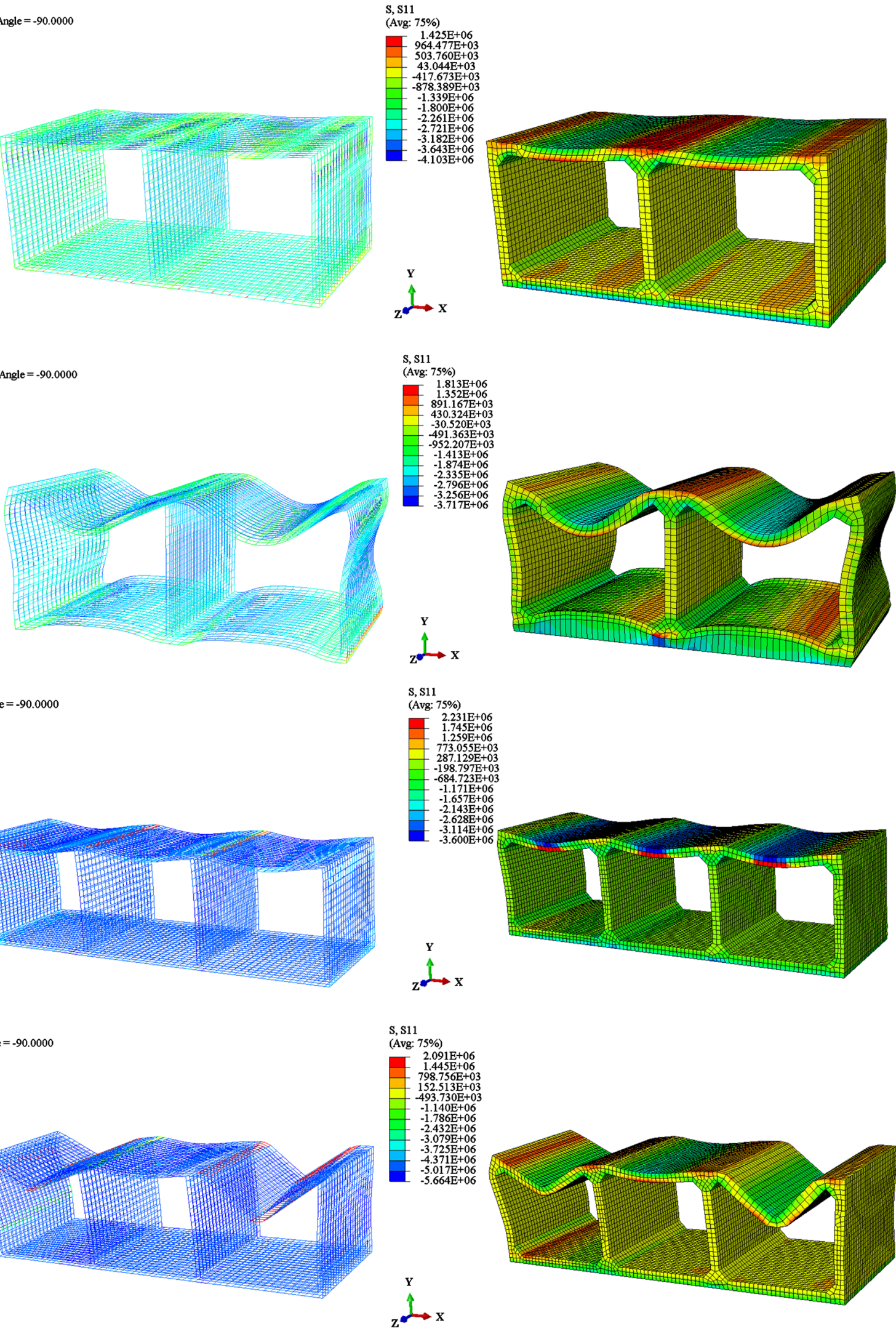

Figure 13. The horizontal direction stresses contour: El Centro: (a) and (c); Kobe: (b) and (d). 
prediction for adjacent longitudinal precast box culvert and subject to different loading conditions including different loading area. To verify the seismic behavior of the RBCs and establish a method for evaluating their seismic behavior numerical analyses under near and far-fault ground motions were carried out. Two models of two and three cell reinforced concrete box culvert were considered. Based on interpretations and discussions of the simplified results, the major findings were summarized as follows:

1) A model for reinforced concrete box culvert subjected to both static and seismic loadings can be used to demonstrate the complete step-by-step methodology for evaluation of seismic behavior of reinforced concrete box culvert. The working state of RBCs could be divided into elastic stage and plasticity state [19] [20].

2) The change of seismic responses of the side walls and slabs of RBCs from far and near faults shaking events showed a regular pattern that increases and decreases. The critical responses which should be considered for overall underground seismic assessment should occur under the near fault excitation for the two integral types of structures.

3) As the load increases under the near fault shaking event, the presence of the crack caused the stress in the section to redistribute which verified the validity of the finite element analysis under rare seismic excitation. At the same time, the finite element model indicated that the sliding and rotating behavior would cause the first principal tensile stress of the concrete.

4) The present study confirms that dynamic analysis can be used to evaluate the seismic behavior of RBCs under near and far fault earthquakes and the proposed method is rational, easy to apply, and fulfills engineering need heretofore unfulfilled for a reinforced concrete box culvert installation.

\section{Conflicts of Interest}

The authors declare no conflicts of interest regarding the publication of this paper.

\section{References}

[1] Handke, J.M. and Peterman, R.J. (2014) Developing Short-Span Alternatives to Reinforced Concrete Box Culvert Structures in Kansas. Kansas State University Transportation Center, Manhattan.

[2] Yatsumoto, H., Mitsuyoshi, Y., Sawamura, Y. and Kimura, M. (2018) Evaluation of Seismic Behavior of Box Culvert Buried in the Ground through Centrifuge Model Tests and Numerical Analysis. Underground Space, 4, 147-167. https://doi.org/10.1016/j.undsp.2018.09.007

[3] Yang, J.C. and Kalabuchova, L. (2014) Application of FRP Materials in Culvert Road Bridges. Department of Civil and Environmental Engineering Division of Structural Engineering Steel and Timber Structures, Chalmers University of Technology Göteborg, Göteborg.

[4] Hoevelkamp, K.K. (2002) Rammed Aggregate Pier Soil Reinforcement: Group Load Tests and Settlement Monitoring of Large Box Culvert. A Thesis Submitted to the Graduate Faculty in Partial Fulfillment of the Requirements for the Degree of Master of Science, Iowa State University, Ames. 
[5] Abuhajar, O., El Naggar, H. and Newson, T. (2015). Seismic Soil-Culvert Interaction. Canadian Geotechnical Journal, 52, 1649-1667.

https://doi.org/10.1139/cgj-2014-0494

[6] Eberhard, M.O., Baldridge, S., Marshall, J., Mooney, W. and Rix, G.J. (2010) The MW 7.0 Haiti Earthquake of January 12, 2010: USGS/EERI Advance Reconnaissance Team Report. U.S. Geological Survey, Reston.

https://doi.org/10.3133/ofr20101048

[7] Abuhajar, O.S.A. (2013) Static and Seismic Soil Culvert Interaction (Ss-Sci). A Thesis Submitted in Partial Fulfillment of the Requirements for the Degree of Doctor of Philosophy the School of Graduate and Postdoctoral Studies the University of Western Ontario, London.

[8] Abuhajar, O.S., Hesham El Naggar, M. and Newson, T. (2011) Effects of Underground Structures on Amplification of Seismic Motion for Sand with Varying Density. 14th Pan-American Conference on Soil Mechanics and Geotechnical Engineering and 64th Canadian Geotechnical Conference, Ontario, Canada, 2011, 201-215.

[9] Allen, L.D. and Russ, L.R. (1978) Loads on Culverts under High Embankments, Positive Projection without Imperfect Trench. Research Rep. No. 491, Interim Rep. No. KYHPR-72-68; HPR1 (13), Part II, Department of Transportation, Lexington.

[10] Anderson, D.G., Martin, G.R., Lam, I. and Wang, J.N. (2008) Seismic Analysis and Design of Retaining Walls, Buried Structures, Slopes and Embankment. NCHRP Rep. No. 611, TRB, National Research Council, Washington DC.

[11] Chen, B., Zheng, J. and Han, J. (2010) Experimental Study and Numerical Simulation on Concrete Box Culverts in Trenches. Journal of Performance of Constructed Facilities ASCE, 24, 223-234. https://doi.org/10.1061/(ASCE)CF.1943-5509.0000098

[12] McGuigan, B.L. and Valsangkar, A.J. (2010) Centrifuge Testing and Numerical Analysis of Box Culverts Installed in Induced Trenches. Canadian Geotechnical Journal, 47, 147-163. https://doi.org/10.1139/T09-085

[13] Abuhajar, O., El Naggar, H. and Newson, T. (2015) Experimental and Numerical Investigations of the Effect of Buried Box Culverts on Earthquake Excitation. Soil Dynamics and Earthquake Engineering, 79, 130-148. https://doi.org/10.1016/j.soildyn.2015.07.015

[14] Tsinidis, G., Rovithis, E., Pitilakis, K. and Chazelas, J.L. (2016) Seismic Response of Box-Type Tunnels in Soft Soil: Experimental and Numerical Investigation. Tunnelling and Underground Space Technology, 59, 199-214. https://doi.org/10.1016/j.tust.2016.07.008

[15] Tahmasebinia, F., Ranzi, G. and Zona, A. (2012) Beam Tests of Composite SteelConcrete Members: A Three-Dimensional Finite Element Model. International Journal of Steel Structures, 12, 37-45. https://doi.org/10.1007/s13296-012-1004-3

[16] Tabatabaei, S.A., Lomov, S.V. and Verpoest, I. (2014) Assessment of Embedded Element Technique in Meso-FE Modelling of Fibre Reinforced Composites. Composite Structures, 107, 436-446. https://doi.org/10.1016/j.compstruct.2013.08.020

[17] Garg, A.K. and Abolmaali, A. (2009) Finite-Element Modeling and Analysis of Rein-Forced Concrete Box Culverts. Journal of Transportation Engineering, 135, 121-128. https://doi.org/10.1061/(ASCE)0733-947X(2009)135:3(121)

[18] Daggumati, S., Van Paepegem, W., Degrieck, J., Xu, J., Lomov, S.V. and Verpoest, I. (2010) Local Damage in a 5-Harness Satin Weave Composite under Static Tension: Part II. Meso-FE. Composites Science and Technology, 70, 1934-1941. https://doi.org/10.1016/j.compscitech.2010.07.002

[19] Abuhajar, O., El Naggar, H. and Newson, T. (2015) Seismic Soil-Culvert Interaction. 
Canadian Geotechnical Journal, 1, 1649-1667.

https://doi.org/10.1139/cgj-2014-0494

[20] Gong, Y.F., Ma, Y.L., Tan, G.J., Bi, H.P., Pang, Y.Z. and Ma, C. (2020) Experimental Study and Numerical Simulation on Failure Process of Reinforced Concrete Box Culvert. Advances in Civil Engineering, 2020, Article ID: 5423706.

https://doi.org/10.1155/2020/5423706 